\title{
ЦЕНТР УПРАВЛІННЯ КОМПЕТЕНЦІЯМИ: ВИРІШЕННЯ ПРОТИРІЧ ПУБЛІЧНОГО УПРАВЛІННЯ ЗАВДЯКИ ІНФОРМАЦІЙНИМ ТЕХНОЛОГІЯМ
}

\author{
DOI: $10.32620 /$ cher.2021.1.14
}

Постановка проблеми. У статті досліджено центр управління компетенціями, як засіб вирішення протиріч публічного управління. Визначено, що сутність проблеми полягає в тому, що впровадження інформаційно-комунікативних технологій сприяє розвитку більш високого рівня людського мислення $\mathrm{i}$ мотивації його дій, а відповідно з'являються нові вимоги до стандартів якості державного управління, що тягне за собою загострення протиріч публічного управління. Метою дослідження є формування концептуальних засад створення та функціональної реалізації центру управління компетенціями для вирішення протиріч публічного управління, які виникли внаслі-док використання сучасних інфомаційних технологій. Об'єктом даного дослідження є протиріччя публічного управління обумовлених застосуванням інформаційних технологій та інструменти і засоби їх вирішення. В дослідженні використані загальнонаукові та спеціальні методи: аналізу й синтезу, логічний, діалектичний, метод узагальнення, комплексного і системного підходів. Гіпотезою дослідження є припущення, що протиріччя публічного управління, які обумовлені застосуванням інформаційних технологій можуть бути вирішенні шляхом застосування центру управління компетенціями. Виклад основного матеріалу. 3'ясовано, що основне протиріччя функціонування центру системи управління полягає в тому, що при суттєвій необхідності актуалізації публічного характеру управління вимагає рішення відсутність належних механізмів залучення об'єкта управління, представленого населенням тієї чи іншої території, до участі в процесі формування альтернатив, критеріїв оцінки, аналізу, вибору та втілення в життя управлінських рішень. Оригінальність та практичне значення дослідження. Доведено, що застосування сучасних інструментів публічного характеру управління (розвиток технологій електронного уряду; розвиток інноваційної інформаційно-комунікаційної інфраструктури з використанням можливостей державно-приватного партнерства; використання інструменту політичного маркетингу; впровадження технологій форсайт, краудсорсингу та публічного аудиту) не досить ефективно сприяє вирішенню вищевказаних протиріч. Висновки дослідження. В якості перспективного інструментарію пропонується центр управління компетенціями, що сприяє вирішенню протиріч, які загострюються в умовах впровадження інформаційно-комунікаційних технологій.

Ключові слова:

центр управління компетенціями, публічне управління, протиріччя публічного управління, інформаційно-комунікаційні технології, електронний уряд, державно-приватне партнерство.

1 Дєгтяр Андрій Олегович, д-р наук з держ. упр., професор, професор кафедри публічного управління та підприємництва, Національний аерокосмічний університет ім. М. С. Жуковського «Харківський авіаційний інститут», м. Харків, Україна.

Diegtiar Andrii, Doctor of Public Administration Science, Professor, Professor of Public Administration and Entrepreneurship Department, National Aerospace University «Kharkiv Aviation Institute», Kharkiv, Ukraine.

ORCID ID: 0000-0003-3258-447X

e-mail: ADegtyar@3g.ua

${ }^{2}$ Ковальчук Вероніка Геннадіївна, д-р наук з держ. упр., професор, завідувач кафедри публічного управління та підприємництва, Національний аерокосмічний університет ім. М. Є. Жуковського «Харківський авіаційний інститут», м. Харків, Україна.

Kovalchuk Veronika, Doctor of Public Administration Science, Professor, Head of Public Administration and Entrepreneurship Department, National Aerospace University «Kharkiv Aviation Institute», Kharkiv, Ukraine.

ORCID ID: 0000-0001-5321-8300

e-mail: covveron@ukr.net

${ }^{3}$ Бублій Максим Петрович, канд. наук з держ. упр., доцент кафедри економіки праці та управління персоналом, Харківський регіональний інститут державного управління Національної академії державного управління при Президентові України, м. Харків, Україна.

Bubliy Maxim, Ph.D. in Public Administration Associate Professor of economies of labour and management by personnel Department, Kharkiv Regional Institute of Public Administration, Kharkiv, Ukraine.

ORCID ID: 0000-0003-1060-6404

e-mail: mbubliy@gmail.com 


\section{COMPETENCE MANAGEMENT CENTER: RESOLUTION OF CONTRACTS OF PUBLIC GOVERNANCE THANKS TO INFORMATION TECHNOLOGIES}

Problem statement. The article examines the competence management center as a means of resolving contradictions in public administration. It is determined that the essence of the problem lies in the fact that the introduction of information and communication technologies contributes to the development of a higher level of human thinking and motivation for its actions, and accordingly there are new requirements for the quality standards of public administration, which leads to an aggravation of the contradictions of public administration. The purpose of the study is formation of conceptual bases of creation and functional realization of the center of management of competences for the decision of contradictions of public management which have arisen owing to use of modern information technologies. The object of this research is the contradictions of public administration caused by the use of information technologies and tools and means of their solution. The research uses general scientific and special methods: analysis and synthesis, logical, dialectical, generalization method, complex and systematic approaches. Research methods: in the process of scientific work were used general and special methods of scientific abstraction, induction and deduction, statistical analysis, analogy and quantitative and qualitative comparison. The research hypothesis is the assumption that the contradictions of public administration that are caused by the use of information technologies can be resolved by applying the competence management center. Presentation of the main material. It is found out that the main contradiction of the functioning of the management system is that if there is a significant need to update the public nature of management, the lack of proper mechanisms for attracting the object of management represented by the population of a particular territory to participate in the process of forming alternatives, evaluation criteria, analysis, selection and implementation of management decisions requires a solution. Originality and practical significance of the research. It is proved that the use of modern public management tools (development of e-government technologies; the development of innovative information and communication infrastructure using public-private partnership opportunities; the use of a political marketing tool; the introduction of foresight, crowdsourcing and public audit technologies) does not contribute effectively enough to resolving the above contradictions. Conclusions and prospects for further research. As a promising tool, a competence management center is proposed, which helps to resolve contradictions that are becoming more acute in the context of the introduction of information and communication technologies.

Key words:

competence management center, public administration, contradictions of public administration, information and communication technologies, e-government, public-private partnership.

\section{ЦЕНТР УПРАВЛЕНИЯ КОМПЕТЕНЦИЯМИ: РЕШЕНИЕ ПРОТИВОРЕЧИЙ ПУБЛИЧНОГО УПРАВЛЕНИЯ ПОСРЕДСТВОМ ИНФОРМАЦИОННЫХ ТЕХНОЛОГИЙ}

Постановка проблемы. В статье исследованы центр управления компетенциями, как средство разрешения противоречий публичного управления. Определено, что сущность проблемы заключается в том, что внедрение информационно-коммуникативных технологий способствует развитию более высокого уровня человеческого мышления и мотивации его действий, а соответственно появляются новые требования к стандартам качества государственного управления, влечет за собой обострение противоречий публичного управления. Целью исследования является формирование концептуальных основ создания и функциональной реализации центра управления компетенциями для решения противоречий публичного управления, возникшие в результате использования современных инфомацийний технологий. Объектом данного исследования является противоречие публичного управления, обусловленных применением информационных технологий и инструменты и средства их решения. В исследовании использованы общенаучные и специальные методы: анализа и синтеза, логический, диалектический, метод обобщения, комплексного и системного подходов. Гипотезой исследования является предположение, что противоречия публичного управления, которые обусловлены применением информационных технологий могут быть решены путем применения центра управления компетенциями. Изложение основного материала. Установлено, что основное противоречие функционирования системы управления заключается в том, что при существенной необходимости актуализации публичного характера управления требует решения отсутствие надлежащих механизмов привлечения объекта управления, представленного населением той или иной территории, к участию в процессе формирования альтернатив, критериев оценки, анализа, выбора и осуществления управленческих решений. Оригинальность и практическое значение исследования. Доказано, что применение современных инструментов публичного характера управления 
(развитие технологий электронного правительства, развитие инновационной информационнокоммуникационной инфраструктуры с использованием возможностей государственно-частного партнерства, использование инструмента политического маркетинга, внедрение технологий форсайт, краудсорсинга и публичного аудита) недостаточно эффективно способствует решению выщевказаних противоречий. Выводы исследования. В качестве перспективного инструментария предлагается центр управления компетенциями, что способствует разрешению противоречий, которые обостряются в условиях внед-ния информационно-коммуникационных технологий.

\section{Ключевые слова:}

центр управления компетенциями, публичное управление, противоречия публичного управления, информационно-коммуникационные технологии, электронное правительство, государственночастное партнерство.

Постановка проблеми. Початок третього тисячоліття висуває нові вимоги до стандартів якості державного управління, більш високого рівня людського мислення і мотивації його дій, що тягне за собою загострення протиріч публічного управління. Тому необхідно їх розглядати, як протиріччя, що формується в процесі розвитку управлінських відносин, виникнення яких визначається протилежністю поглядів і прагнень суб'єкта і персоніфікованого об'єкта управління, між якими здійснюються управлінські інтеракції.

Причинами загострення протиріч в системі публічного управління $€$ особливості функціонування, пов'язані зі складно організованістю їі елементів, і функціонально недостатня дієвість механізму координаційної взаємодії вертикальних і горизонтальних рівнів системи. У зв'язку з цим, система публічного управління функціонує в умовах прояву безлічі протиріч, як основоположних, так i похідних від них. Необхідно сконцентруватися на одному основоположному протиріччі i похідних від нього, загострення яких має місце в контексті прикладного застосування інформаційно комунікаційних технологій, а також при формуванні системи публічного управління на основі центру управління компетенціями. Суть основного протиріччя функціонування системи управління полягає в тому, що при суттєвій необхідності актуалізації публічного характеру управління вимагає рішення відсутність належних механізмів залучення об'єкта управління, представленого населенням тієї чи іншої території, до участі в процесі формування альтернатив, критеріїв оцінки, аналізу, вибору та втілення в життя управлінських рішень.

Аналіз останніх досліджень і публікацій. Теоретичні і практичні аспекти діяльності публічного управління висвітлені в працях як зарубіжних, так і вітчизняних вчених. Вагомий внесок у вирішення протиріч публічного управління зробили такі вчені, Гапоненко Н. В. [1], Ковбасюк Ю. В. [2], Круглов В. В. [3], Марченко В. В. [4], Міненко М. А. [5], Пастернак О. І. [6], Хаджирадєва С. К., [9] Воронова С. В., [9] Кравцова Н. С. [9], Цвєтков В. В. [10], Горбатенко В. П. [10] та ін. Однак, незважаючи на численні дослідження, проблема вирішення протиріч публічного управління обумовлених застосуванням інформаційних технологій залишається однією з актуальних при дослідженні сучасних процесів.

Мета статті $\epsilon$ формування концептуальних засад створення та функціональної реалізації центру управління компетенціями для вирішення протиріч публічного управління, які виникли внаслідок використання сучасних інфомаційних технологій.

Виклад основного матеріалу дослідження. Узгодження різноспрямованих індивідуальних інтересів виступає необхідним елементом процесу життєдіяльності системи публічного управління. На думку окремих авторів в якості загальнозначимої характеристики поведінки речей слід виділити неможливість розгляду їх дії поза взаємозв'язку 3 положенням інших речей. Осмислення і аналіз плодів спільної діяльності людей уможливлює планування цілеспрямованих дій, що гарантують досягнення поставлених цілей i нівелювання негативних відхилень. Таким чином, сприйняття наслідків породжує спільність інтересів [5, с. 61]. Для виходу 3 проблемної ситуації, пов'язаної зі слабким ступенем залученості об'єкта управління в процес підготовки та втілення в життя управлінських рішень в контексті розвитку системи публічного управління шляхом прикладного застосування новаційних інформаційнокомунікаційних технологій необхідна передача ініціативи вирішення завдань, що мають підвищений суспільний резонанс органів державного i місцевого управління в руки 
громадських структур, асоційованих дослідників поруч 3 об'єктом управління з закріпленням за ними певних прав і обов'язків [5, с. 63].

Події, що відбуваються у галузі управління визначають динамічне перетворення методології управління i, в значній мірі, забезпечуються динамічними змінами в технічних, організаційних системах, а також загальної логіки розвитку суспільних інститутів [9, с. 36]. У сучасних умовах швидкозмінного зовнішнього середовища традиційні адміністративно-бюрократичні моделі управління в умовах, стають недостатньо гнучкими, вимагають розвитку. На думку В. Цвєткова та В. Горбатенко, бюрократизм як інститут управління спрямований на встановлення тотального контролю над іншими громадськими інститутами [10, с. 36].

Ускладнення керуючої системи є закономірним при зростанні і розвитку керованої системи [10, с. 47]. Така відповідність за параметром складності досягається за рахунок збільшення рівнів управління, що полягає в причинно-наслідковому зв'язку 3 процесом інтенсифікації централізації бюрократичної організації, контролюючий генерацію і трансляцію сигналів системи управління, формування багаторазово дубльованих підсистем, а також підвищення ступеня зв'язності організаційної структури, що має тенденцію до «розпушення».

Відповідно, така стратегія стає з часом неоптимальною, збільшуються витрати на підтримку органів управління в робочому стані, що важким тягарем лягає на державний бюджет.

Серйозніші недоліки бюрократичної моделі управління державних органів полягають у невиправдано тривалому управлінському циклі, який, до того ж, на виході породжував цілком стандартні, передбачувані рішення, що не відповідають динамічному середовищу системи державного управління [7, c. 54$]$.

В даний час в рамках вдосконалення системи публічного управління сучасні апаратні та програмні засоби відкривають нові можливості для взаємодії між учасниками публічного процесу.

Таким чином, за результатами проведеного аналізу можна зробити висновок про те, що публічний характер управління забезпечує реалізацію поставлених цілей, виходячи 3 реальних можливостей i потреб соціальної системи.

На сучасному етапі розвитку публічного характеру управління використовуються такі інструменти:

- технології електронного уряду;

- алгоритми побудови інноваційної інфраструктури в тісному взаємозв'язку з розвитком прикладних механізмів державноприватного партнерства [3, с. 67];

- маркетингові інструменти, орієнтовані на формування позитивного образу політики органів державної влади;

- технологічні новації у сфері краудсорсингу, форсайту та публічного аудиту.

У процесі теоретичного осмислення поняття «електронний уряд» виявлено, що одні автори трактують визначення «електронного уряду», - як інформаційну взаємодію органів влади 3 представниками громадянського суспільства та бізнесу 3 використанням інформаційно-комунікаційних, мережевих технологій та інтернету [4, с. 48]; другі - як концепцію здійснення державного управління, притаманну інформаційному суспільству. Концепція передбачає розвиток інститутів громадянського суспільства при найбільш повному використанні потенціалу інформаційно-комунікаційних технологій, характеризується економічною ефективністю, стимулюванням громадської ініціативи та вдосконаленням механізмів публічного контролю [8, с. 94].

Таким чином, електронний уряд виступає як інституційно оформлена інноваційна технологія, що надає розширені можливості взаємодії представників публічного управління за допомогою застосування комунікаційних засобів зв'язку, в тому числі мережі інтернет, спрямованої на задоволення соціальних потреб, підвищення громадської ініціативи і здійснення контролю, що, в кінцевому підсумку, може сприяти вирішенню вищезазначених протиріч публічного управління.

Аналіз цілей впровадження електронного уряду дозволяють трактувати його як механізм вирішення протиріч державного управління та посилення його публічного характеру. Однією з важливих цілей електронного уряду є розширення участі громадян у вирішенні суспільно значущих завдань, задоволенні потреб населення за допомогою широкого доступу до інформації в усіх напрямках життєдіяльності суспільства та діяльності державних органів.

В останні десятиліття в якості провід- 
ного вектора соціально-економічного розвитку дослідники виділяють співпрацю влади і приватних підприємницьких структур. Інститут державно-приватного партнерства шляхом об'єднання ресурсів державного і приватного секторів дозволяє досягати безліч інноваційних, соціальних, інфраструктурних цілей.

У зв'язку з цим, найбільш поширений характер набуває вдосконалення інструментів державно-приватного партнерства, що створює умови безперешкодної конкурентної боротьби, рівноправного доступу економічних суб'єктів, незалежно від їх афілійованості органам влади до суспільних благ і ресурсів, в тому числі тим, доступ до яких регламентований. На погляд автора, найважливішим критерієм повинен розглядатися суспільний інтерес, відображений інтегральним способом, а не вигода конкретних суб'єктів економічної діяльності. Така взаємодія сприятиме якісній зміні національної економіки та вирішенню суперечностей публічного управління, дозволить підвищити ефективність функціонування громадського сектору.

В рамках розвитку публічного характеру управління доцільно говорити про розвиток державно-приватного партнерства. Вищевказані концепти компліментарні, утворюють вузлові точки зростання інтеракції державних органів управління і бізнесом.

У контексті розвитку публічного характеру управління раціонально висунути наступну градацію стадії впровадження політики державно-приватного партнерства:

- виявлення напрямів, що визначають необхідність і доцільність впровадження механізмів державно-приватного партнерства;

- ідентифікація перспективних напрямків впровадження приватних бізнес-структур у механізми державно-приватного партнерства та аналіз виникаючих проблем;

- виявлення та повідомлення бізнесструктур про можливості взаємодії з докладним викладом обмежень і відповідальності сторін, потенційної вигоди;

- забезпечення умов використання необхідних ресурсів та регламентування процедур взаємодії;

- моніторинг підвищення ефективності публічного управління в контексті імперативів підвищення ефективності механізмів державно-приватного партнерства.

Одним із значущих інструментів посилення публічного характеру управління $\epsilon$ ма- ркетинг державної політики. Рішення, які приймаються державою, часто викликають значний резонанс і невдоволення окремих соціальних груп, якщо не виносяться на загальне обговорення і громадську консультацію. Усунути протиріччя публічного управління, знизити соціальну апатію населення без активного використання маркетингу в даний час проблематично. Відповідно до досліджень, що проводяться в системі маркетингу, доцільно розглянути такі його різновиди як державний і муніципальний маркетинг, маркетинг території. Основною метою державного маркетингу, в першу чергу, має бути максимальне задоволення потреб громадян в рамках, виділених на ці цілі суспільних витрат [11, с. 69].

Державний маркетинг, як правило, використовується для роз'яснення цілей і завдань суспільного розвитку, забезпечення стабільності в державі, формування позитивного іміджу держави. Державний маркетинг як інструмент публічного характеру управління спрямований на виявлення і формування потреб членів суспільства, створення відповідних умов і здійснення конкретних дій і заходів щодо їх задоволення.

Використання інструментів державного маркетингу необхідно 3 метою формування сприятливого ставлення до державної політики, що проводиться на певній території, створення ідентичності населення, що проживає на ній. У науковій літературі виділяються такі поняття як маркетинг території i муніципальний маркетинг. Деякі автори говорять про те, що «маркетинг території» являє собою діяльність 3 просування позитивної інформації про продукцію, що випускається на території, з розвитку інституційних умов здійснення підприємницької діяльності, підвищення якості життя населення, 3 наміром формування сприятливої репутації території як серед населення, так і зовні [6, с. 75].

Технологія форсайт передбачає алгоритм формування ідеального образу в перспективі, спрямованого на зростання якості рішень та їх координацію з точки зору очікуваного майбутнього результату. Згідно 3 визначенням Н Гапоненка, форсайт - це методичний, регулярний аналіз довгострокових перспектив економіки, технологій, інновацій, спрямований на визначення пріоритетних напрямків досліджень, що забезпечують максимальний соціально-економічний ефект [1, с 63]. Таким чином, головна мета форсайта по- 
лягає у визначенні майбутнього i розробці стратегії його досягнення.

Форсайт - це процес співпраці між державою, представниками громадянського суспільства і бізнесу, націлених на прийняття спільного, що задовольняє інтересам всіх в тій чи іншій мірі рішень, шляхом розробки та аналізу передбачуваних сценаріїв розвитку. Реалізація форсайт-проекту здійснюється на корпоративному, місцевому, регіональному, національному та глобальному рівнях. Водночас необхідна організація прозорої дискусії на відкритих майданчиках, доступних усім зацікавленим сторонам.

Краудсорсинг і публічний аудит є дієвими інструментами вирішення основоположного протиріччя публічного управління, оскільки припускають залучення громадян до процесу цілепокладання, прийняття та реалізації рішень, спрямований на задоволення споживачів державних владних послуг у контексті вирішення завдань державної важливості. Публічний аудит являє собою історично сформовану форму контролю представників громадянського суспільства і бізнесструктур за діями державних органів влади.

Впровадження інструментарію публічного аудиту та краудсорсингу дає синергетичний ефект від групової взаємодії, так як у окремого індивіда менше знань, ніж у групи людей, але головна мета технології полягає в створенні умов для агрегування і реалізації зазначених знань. При цьому, формується якісно новий економічний, соціальний, політичний простір, для якого характерні соціальна згуртованість, соціальна справедливість, Соціальні та культурні цінності; економічна, соціальна, політична стабільність. Це кардинальним чином змінює поведінку населення і його мотивацію: люди отримують можливість впливати на прийняття рішень, що безпосередньо зачіпають їх життєві інтереси, усвідомлення чого збільшує ступінь соціальної відповідальності [2, С. 350].

У процесі проведеного дослідження нами виділено ряд похідних протиріч, які проявляються в умовах публічного характеру управління за допомогою вищевказаного інструментарію. Дане протиріччя обумовлено необхідністю відповідності системи управління принципам достовірності, адекватності обсягу і якості інформації, траспарентності, 3 метою нівелювання загроз, пов'язаних 3 виникненням так званих «деформацій», а саме спотворення i зниження якості інформації, що служить для прийняття рішень. У зв'язку з вищевикладеним необхідно акцентувати увагу на інформаційному обміні даними як всередині конкретного органу влади, так і між елементами системи публічного управління в цілому, але в реальній дійсності існує навмисна чи об'єктивно виникача асиметрія інформації, що доповнюється великими часовими затримками її ретрансляції, в результаті чого, суб'єкт прийняття управлінських рішень часто використовує неактуальну інформацію.

Другим похідним протиріччям від основного протиріччя в умовах розвитку інформаційно-комунікаційних технологій, на наш погляд, є протиріччя між актуалізованою потребою зростання залученості учасників керуючої і керованої підсистем публічного управління в інформаційний обмін, з одного боку, і нерівномірність формування технологічної бази реалізації комунікаційних можливостей сучасного суспільства (технологічним дисбалансом), що призводить до зниження стійкості розвитку суспільства.

В якості третього істотного похідного від основоположного протиріччя, на наш погляд необхідно виділити протиріччя, пов'язане 3 вимогами інтерактивної участі населення в процесах прийняття і втілення в життя рішень, що мають підвищене суспільне значення, з одного боку, і шаблонами в сприйнятті представниками громадськості інформаційно-комунікаційної мережі «Інтернет», як розважального середовища перш за все, 3 іншого i, як наслідок, зниження рівня довіри до рішень органів державного і муніципального управління в умовах здійснення їх діяльності в інтерактивному режимі.

У рамках дослідження передбачається, що вирішенню зазначених проблемних місць посприяє удосконалення системи публічного управління, шляхом впровадження інноваційного інструментарію центру управління компетенціями. У зв'язку з чим, пропонується розглянути процес залучення населення до керуючого впливу в режимі реального часу, що знаходить своє вираження в залученні інтелектуального потенціалу населення в процес прийняття і реалізації рішень. Як один 3 основоположних результатів створення системи публічного управління знаннями, на наш погляд, доцільно виділити синергію інтеракції інновацій та інтелектуальних ресурсів представників громадськості, залучених до публічної взаємодії суб'єктів системи управління 
Основні функції центру управління компетенціями повинні зводиться як до виявлення, накопичення та акумулювання знань у певній галузі, так і роботі з експертним співтовариством.

У зв'язку з тим, що в рамках дослідження центр управління компетенціями розглядається як інструмент системи публічного управління, а також враховуючи територіальну роз'єднаність акторів публічного управління та функціональні можливості центру управління компетенціями нами виявлено протиріччя, загострення яких можливе в процесі функціонування центру публічного управління компетенціями.

Перше - між суттєвою необхідністю координації даних та процедур на базі єдиного центру управління компетенціями та низькими технологічними можливостями учасників публічного процесу (органи влади, підприємницькі структури, населення).

Друге - між необхідністю вироблення управлінських рішень на базі центру управління компетенціями, з одного боку, і наявністю відповідальності за вироблення і реалізацію управлінських рішень в рамках діяльності компетентних державних органів, з іншого, i, як наслідок дублювання функцій між ними.

Таким чином, раціональна розробка та аналіз функціональних можливостей центру компетенцій на рівні публічного управління сприятимуть як вирішенню та недопущенню виявлених похідних протиріч, так і збереженню, генерації та акумулюванню нових знань і досвіду експертів на території всієї держави.

Резюмуючи вищевикладене слід зазначити, що основоположне протиріччя розвивається між бюрократичним характером і публічним характером управління, виступаючим його антиподом. Порівняльний аналіз бюрократичного і публічного характеру управління, модифікація якого простежується в умовах розвитку інформаційно-комунікаційних технологій, свідчить про необхідність переходу до останнього через формування та функціональної реалізації центру управління компетентностями.

Висновки і перспективи подальших досліджень. Дослідження концептуальних засад створення та функціональної реалізації центру управління компетенціями як основного протиріччя сучасного публічного управління дозволило виділити похідні від нього суперечності, посилення яких обумовлено процесом прикладного застосування інформаційно-комунікаційних технологій управління, серед яких: протиріччя між викликами зростання ступеня активності інформатизації суб'єктів публічного управління та комунікаційно-технологічними ресурсами суспільства на даний період розвитку з урахуванням технологічного дисбалансу (нерівномірності технологічного розвитку);протиріччя між вимогами до обсягу та якості, достовірності, інформації, використовуваної для прийняття важливих рішень і розвитком бар'єрів сприйняття інформації, що знижують іiі якість і транспарентність; між потребою інтерактивної участі представників громадськості в процесі вироблення та втілення в життя управлінських рішень, і шаблонами сприйняття інформаційно-телекомунікаційної мережі «Інтернет», як сфери розваг, що тягне за собою критичне ставлення населення до рішень органів державної та муніципальної влади розміщених в цій мережі.

Застосування сучасних інструментів управління компетентностями публічного характеру : розвиток технологій електронного уряду; розвиток інноваційної інформаційно-комунікаційної інфраструктури з використанням можливостей державно-приватного партнерства; використання інструменту політичного маркетингу; впровадження технологій форсайт, краудсорсингу та публічного аудиту не досить ефективно сприяє вирішенню вищевказаних протиріч. В якості перспективного інструментарію пропонується центр управління компетенціями, що сприяє вирішенню протиріч, які загострюються в умовах впровадження інформаційно-комунікаційних технологій

\section{Література}

1. Гапоненко Н. В. Форсайт. Теория. Методология. Onылт: монография. Москва: Юнити-Дана, 2012. 239 с.

2. Ковбасюк Ю. В. Краудсорсинг як інструмент публічної влади. Актуальні проблеми економіки. 2016. № 4. С. 349-357.

3. Круглов В. В. Розвиток державноприватного партнерства в Украйні: механізми державного регулювання: монографія. Харків: Вид-во ХарРІ НАДУ «Магістр», 2019. 252 с.

4. Марченко В. В. Електронне урядування в органах виконавчої влади: адміністративно-правові засади : моно- 
графія. Харків : Панов, 2016. 444 с

5. Міненко М. А. Публічне управління: теорія та методологія : монографія. Київ: Київ. нац. торг.-екон. ун-т, 2014. 404 с.

6. Пастернак О. I. Економічний розвиток регіону: маркетингове забезпечення: монографія. Львів: НАН України. Ін-т регіональних досліджень, 2009. 200 с.

7. Проблеми реформування державної служби та служби в органах місиевого самоврядування в Україні: монографія / за заг. ред. Т.Е. Василевської. Київ: НАДУ, 2018. $256 \mathrm{c}$

8. Публічне управління та адміністрування в умовах інформаційного суспільства: вітчизняний $i$ зарубіжсний досвід: монографія / За заг. ред. С. Чернова, В. Воронкової, В. Банаха, О. Сосніна, П. Жукаускаса, Й. Ввайнхардт, Р. Андрюкайтене; Запоріз. держ. інж. акад. Запоріжжя: ЗДІА, 2016. $606 \mathrm{c}$.

9. Хаджирадєва С. К., Воронова С. В., Кравцова Н. Є. Професіоналізація у сфері публічного управління: стан, проблеми, перспективи вирішення: монографія / за заг. ред. С. К. Хаджирадєвої. Миколаїв: Смельянова Т. В., 2017. Ч. II. 165 c.

10. Цвєтков В. В., Горбатенко В. П. Демократія - Управління - Бюрократія: 6 контексті модернізачії украӥнського суспільства: монографія. Київ: Інститут держави і права ім. В. М. Корецького НАН України, 2001. 248 c.

11. Чаплай I. В., Романенко Є. О. Маркетинг у механізмах державного управління: монографія. Київ: ДП «Вид. дім «Персонал», 2016. 208 c.

\section{References}

1. Gaponenko, N. V. (2012). Foresight. Theory. Methodology. Experience. Moscow: Unity-Dana, 239.

Стаття надійшла

до редакції : 15.02 .2020 p.
2. Kovbasiuk, Yu. V. (2016). Crowdsourcing as an instrument of public authority. Actual problems of economy, 4, 349-357.

3. Kruhlov, V. V. (2019). Development of state-private partnership in Ukraine: mechanisms of state regulation. Kharkiv: Magistr, 252.

4. Marchenko, V. V. (2016). Electronic regulation in the organs of the viconavcha power: administrative-legal ambush. Kharkiv: Panov, 444.

5. Minenko, M. A. (2014). Public administration: theory and methodology. Kyiv: Kyiv. nats. torh.-ekon. un-t, 404.

6. Pasternak, O. I. (2009). Economic development of the region: marketing protection. Lviv: NAS of Ukraine. Institute of Regional Studies, 200.

7. Vasylevska, T. E. (Ed.). (2018). Problems of reforming the state service and service in the bodies of the local self-assembly in Ukraine. Kyiv: NADU, 256.

8. Chernov, S., Voronkova, V., Banakh, V., Sosnin, O., Zhukauskas, P., Vvainkhardt, Y., Andriukaitene, R. (Eds.). (2016). Public administration and administration in the minds of information support: revision and foreign information. Zaporizhzhia: ZDIA, 606.

9. Khadzhyradieva, S. K., Voronova, S. V., Kravtsova, N. I. (2017). Professionalism in the sphere of public administration: camp, problems, perspectives of publication. Mykolaiv: Yemelianova T. V., 165.

10. Tsvietkov, V. V., Horbatenko, V. P. (2001). Democracy - Management - Bureaucracy: in the context of modernization of the Ukrainian government: monograph. Kyiv: Instytut derzhavy i prava im. V.M. Koretskoho NAN Ukrainy, 248.

11. Chaplai I. V., Romanenko Ye. O. (2016). Marketing at the mechanisms of state management: monograph. Kyiv: DP «Vyd. dim «Personal», 208.

\footnotetext{
Стаття прийнята

до друку: 29.03.2021 p.
}

\section{Бібліографічний опис для цитування :}

Дєгтяр А. О. Центр управління компетенціями, як засіб вирішення протиріч публічного управління обумовлених застосуванням інформаційних технологій / А. О. Дєгтяр, В. Г. Ковальчук, М. П. Бублій // Часопис економічних реформ. - 2021. - № 1 (41). - С. 117-124. 